\section{EDITORIAL ADDRESS}

The second issue of volume one of The Journal of the Council for Research on Religion (JCREOR) goes back to a colloquium hosted at the McGill School of Religious Studies in 2018 that focused on the 500th anniversary of the Reformation in light of the rich, many sided, and often conflict-laden relations between the Reformation and the world's religions.

Presented in this issue are a selection of papers from the Colloquium which address a variety of topics related to the history of the Reformation and its relationship to the Catholic Church, Judaism, Islam, Indigenous Peoples, and inter-religious dialogue. A central question in all papers concerns learning from the past: what can we learn from the past to make our present and future better, especially in the context of interreligious complexity in Quebec and Canada and in light of the growing influence of religion and globalization.

A special thanks goes to the Presbyterian College for a significant financial contribution towards both the Colloquium and this Issue.

- Gerbern S. Oegema

\section{JCREOR}

(ISSN 2563-0288 online) is published twice a year (Spring/Summer and Fall/Winter) by the McGill University Library Open Access Publications (Montreal, Quebec).

JCREOR was born out of the McGill Center for Research on Religion (CREOR), which was active from 2006 to 2019. The journal is a web-based refereed interdisciplinary journal that publishes articles on all aspects of the scholarly study of religion. Subject matter ranges from the ancient to the contemporary and explores western and non-western perspectives and approaches.

\section{EDITORS/ RÉDACTEURS}

Chief Editor/ Rédacteur en Chef

Gerbern S. Oegema

McGill Univerisity

Editors / Rédacteur

Amanda Rosini

McGill University

Elyse MacLeod

McGill University

\section{EDITORIAL} ADVISORY BOARD/ COMITÉ DE RÉDACTION

VOLUME 1 ISSUE 2

W.J. Torrance Kirby

McGill University

Jim Kanaris

McGill University

Sara Parks

University of Nottingham

Matthew R. Anderson

Concordia University

Lucinda Mosher

Hartford Seminary

Alyson Huntly

Montreal UTC College

John Craig

Simon Fraser University 